This item was submitted to Loughborough's Research Repository by the author.

Items in Figshare are protected by copyright, with all rights reserved, unless otherwise indicated.

\title{
Submarine landforms and shallow acoustic stratigraphy of a 400 km-long fjord-shelf-slope transect, Kangerlussuaq margin, East Greenland
}

PLEASE CITE THE PUBLISHED VERSION

http://dx.doi.org/10.1016/j.quascirev.2010.06.006

PUBLISHER

(C) Elsevier Ltd.

VERSION

AM (Accepted Manuscript)

LICENCE

CC BY-NC-ND 4.0

\section{REPOSITORY RECORD}

Dowdeswell, Julian A., Jeff Evans, and Colm O Cofaigh. 2019. "Submarine Landforms and Shallow Acoustic Stratigraphy of a $400 \mathrm{Km}$-long Fjord-shelf-slope Transect, Kangerlussuaq Margin, East Greenland". figshare. https://hdl.handle.net/2134/13098. 
This item was submitted to Loughborough's Institutional Repository (https://dspace.lboro.ac.uk/) by the author and is made available under the following Creative Commons Licence conditions.

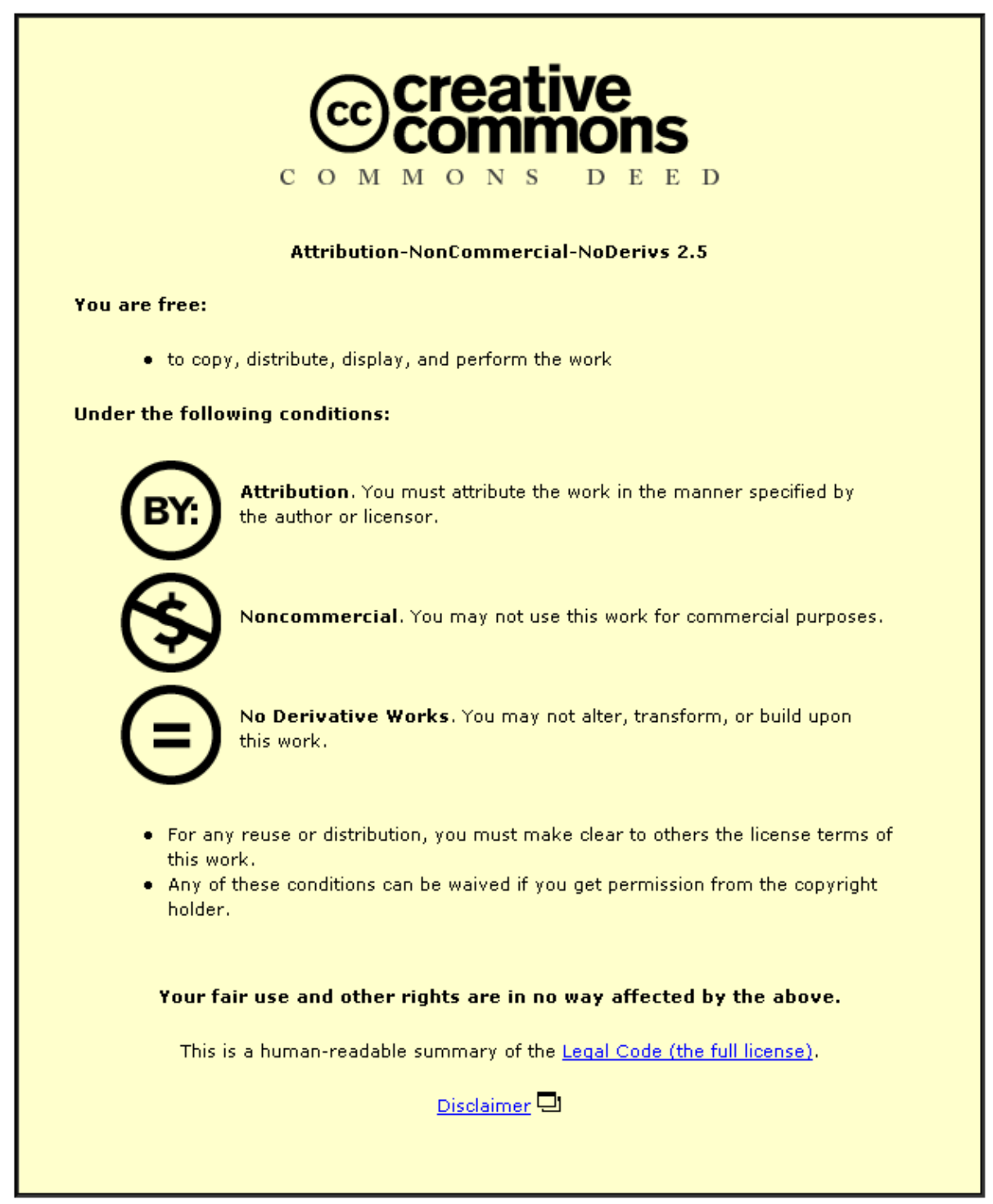

For the full text of this licence, please go to: http://creativecommons.org/licenses/by-nc-nd/2.5/ 
Submarine landforms and shallow acoustic stratigraphy of a $400 \mathrm{~km}-\mathrm{long}$ fjord-shelf-slope transect, Kangerlussuaq margin, East Greenland

\author{
J.A. Dowdeswell ${ }^{1}$, J. Evans ${ }^{2}$, C. Ó Cofaigh ${ }^{3}$ \\ ${ }^{1}$ Scott Polar Research Institute, University of Cambridge, Cambridge CB2 1ER, UK \\ ${ }^{2}$ Department of Geography, Loughborough University, Loughborough LE11 3TU, UK \\ ${ }^{3}$ Department of Geography, Durham University, Durham DH1 3LE, UK
}

\begin{abstract}
Kangerlussuaq Fjord is a relatively uniform, steep-walled basin, whose floor has an almost smooth surface. Debris is supplied mainly from icebergs from the fast-flowing Kangerlussuaq Glacier. Sedimentation after iceberg release from multiyear sea ice is mainly by rain-out of fine-grained englacial debris. Streamlined glacial lineations and drumlins were produced at the sedimentary bed of an ice sheet that expanded into Kangerlussuaq Trough at the Last Glacial Maximum (LGM). Bedrock channels and crescentic overdeepenings indicate warm-based ice and free water beneath parts of the former ice sheet. Cross-cutting iceberg scour marks, which characterise outer Kangerlussuaq shelf, were produced not only during deglaciation, but also occasionally through the Holocene by deep-keeled icebergs from further north in East Greenland. The outward-convex contours of the shelf edge and slope beyond Kangerlussuaq Trough, and debris flows on the slope, suggest a glacierinfluenced high-latitude fan. The distribution of streamlined subglacial landforms demonstrates that the Greenland Ice Sheet extended throughout Kangerlussuaq Fjord and reached at least $200 \mathrm{~km}$ across the shelf in Kangerlussuaq Trough at the LGM. Streamlined-landform orientation indicates ice flow from the interior of Greenland down the axis of Kangerlussuaq Trough. There is little evidence for discrete sedimentary depocentres in the trough, implying that ice probably retreated rapidly from the outer and mid-shelf during deglaciation.
\end{abstract}

\title{
Introduction
}

During Quaternary glacial periods, glaciers and ice sheets expanded along fjords and across continental shelves, sometimes reaching the shelf edge, on many high- 
latitude margins in the Arctic and Antarctic (e.g. Mienert et al., 1992; Anderson et al., 2002; Ottesen et al., 2005; Ó Cofaigh et al., 2005a; Evans et al., 2006, 2009; Ottesen and Dowdeswell, 2009). Submarine landforms, produced by the action of these ice masses, contain a record of the past extent, flow directions and processes that took place at the ice-bed interface. The basal boundary of glaciers and ice sheets is of considerable significance to our understanding of glaciological processes, but it is a location hidden by a kilometre or more of ice in modern polar settings. Glacier and ice-sheet retreat after the last glacial period has revealed suites of submarine landforms on high-latitude margins, produced at the base of former ice masses. Marine waters have protected these landforms from much of the subsequent erosion to which subaerial landforms have been subjected, although the geomorphic imprint of past glacier activity can be obscured by subsequent deglacial and Holocene sedimentation and through reworking by iceberg ploughing at depths shallower than 400-500 $\mathrm{m}$ in many fjord and shelf systems (e.g. Brett and Zarudzki, 1979; Dowdeswell et al., 1992, 1993; Syvitski et al., 2001).

In this paper, we describe and discuss the submarine landforms, and their implications for modern and Quaternary ice-sheet form and flow, along a transect of about $400 \mathrm{~km}$ from an East Greenland fjord, across the adjacent continental shelf and onto the continental slope (Fig. 1). The area selected, the Kangerlussuaq fjord and shelf system $\left(65^{\circ}-68^{\circ} \mathrm{N}, 30^{\circ}-33^{\circ} \mathrm{W}\right)$, is of particular significance for several reasons. First, this system is fed by one of the ten or so fast-flowing outlet glaciers that drain huge interior basins within the Greenland Ice Sheet. The dynamics of these large outlet glaciers are vital controls on the present and past mass balance of the Greenland Ice Sheet (e.g. Reeh, 1985; Luckman et al., 2006; Rignot and Kanagaratnam, 2006). Secondly, there is still some doubt as to which parts of the East Greenland margin experienced ice-sheet growth to the continental shelf edge at the Last Glacial Maximum (LGM) (Mienert et al., 1992; Funder and Hansen, 1996; Roberts et al., 2008) and diagnostic submarine glacial landforms should assist in resolving this question (e.g. Evans et al., 2002; Evans et al., 2009). Thirdly, Kangerlussuaq Fjord and the cross-shelf trough that extends across the shelf beyond the fjord mouth are, in part at least, deep enough to have avoided major reworking of sea floor geomorphology and shallow stratigraphy by the action of deep-keeled icebergs (Syvitski et al., 2001). The glacial geomorphic record is, therefore, preserved in many 
areas of the transect which we have investigated using the marine-geophysical methods of swath bathymetry and shallow sub-bottom acoustic profiling.

\section{Study Area and Background}

The study area comprises Kangerlussuaq Fjord, whose mouth is at $68^{\circ} 05^{\prime} \mathrm{N}$ $31^{\circ} 40^{\prime} \mathrm{W}$, and the adjacent cross-shelf trough, Kangerlussuaq Trough, that reaches the East Greenland shelf edge at about $65^{\circ} 30^{\prime} \mathrm{N} 31^{\circ} \mathrm{W}$ (Fig. 1A-C). The fjord itself is about $70 \mathrm{~km}$ long and ranges between approximately 5 and $10 \mathrm{~km}$ wide. Nordfjord, Courtauld Fjord, Watkins Fjord and Amdrup Fjord form four smaller fjords, branching up to $20 \mathrm{~km}$ from the trunk of Kangerlussuaq Fjord. The cross-shelf trough is about $300 \mathrm{~km}$ long from fjord mouth to shelf break, making the distance from the terminus of Kangerlussuaq Glacier to the continental shelf edge almost $400 \mathrm{~km}$.

The water depth to about $5 \mathrm{~km}$ beyond the margin of Kangerlussuaq Glacier is unknown, because the presence of 'sikussak', a frozen melange of multi-year sea ice with icebergs embedded within it (Syvitski et al., 1996; Reeh et al., 1999; Dowdeswell et al., 2000), prevented survey-ship access in both 1993 and 2004. Water depth immediately beyond the 1993 sikussak limit was more than $600 \mathrm{~m}$, shallowing within $5 \mathrm{~km}$ to a sill at about $450 \mathrm{~m}$ (Syvitski et al., 1996; Smith and Andrews, 2000). Water deepens offshore of the sill to over $800 \mathrm{~m}$ at and beyond the fjord mouth in an inner-shelf basin. A further sill $<500 \mathrm{~m}$ deep separates the inner and middle shelf basins. The latter is more than $700 \mathrm{~m}$ deep and the trough then shallows to about 400 $\mathrm{m}$ at the shelf edge (Mienert et al., 1992; Syvitski et al., 2001). Either side of the 4060 km-wide Kangerlussuaq Trough, shallower banks reach 200-400 m deep (Syvitski et al., 2001). South of about $66^{\circ} 30^{\prime} \mathrm{N}$, the continental shelf is made up of a thick prograding sedimentary wedge (Stein, 1996).

Regarding glacial history, the maximum ice extent in East Greenland during the LGM or Flakkerhuk (Late Weischelian) full-glacial period was from about 22 to $14,000 \mathrm{yr}$ ago (Funder et al., 1998). The precise limit of full-glacial ice on the 300 km-wide Kangerlussuaq continental shelf is still not clear (Mienert et al., 1992; Andrews et al., 1996; Syvitski et al., 2001), but it is thought that retreat from the general area of the outer-shelf took place shortly after about 17,000 yr ago, reaching the inner shelf by about 15,000 yr ago and the present coast by between 13,600 and 11,500 years ago (Mienert et al., 1992; Jennings et al., 2002, 2006). Ocean 
temperature change, with the inflow of relatively warm Atlantic water into Kangerlussuaq Trough, was important to the relatively rapid deglaciation of the shelf and the high observed sedimentation rates (Mienert et al., 1992; Andrews et al., 1996; Jennings et al., 2006).

Today, one of the major outlet glaciers of the Greenland Ice Sheet, Kangerlussuaq Glacier, drains into Kangerlussuaq Fjord (Reeh, 1985; Dwyer, 1995). Ice discharge from the $51,000 \mathrm{~km}^{2}$ inland basin was about $28 \mathrm{~km}^{3} \mathrm{yr}^{-1}$ in 1996; almost $10 \%$ of the mass loss from the whole ice sheet (Rignot and Kanagaratnam, 2006). In August 2004 the sikussak beyond the terminus of Kangerlussuaq Glacier broke up. Since then, the glacier terminus, which was probably floating, has retreated $5 \mathrm{~km}$ and flow has accelerated from $7 \mathrm{~km} \mathrm{yr}^{-1}$ to $13 \mathrm{~km} \mathrm{yr}^{-1}$ (Luckman et al., 2006; Howat et al., 2007; Joughin et al., 2008). Sikussak breakup and terminus retreat occurred when ocean temperatures in Kangerdlugssuaq Fjord were several degrees warmer than during the previous decade, suggesting that basal melting and thinning of this floating ice contribute to rapid changes in the form and flow of Kangerlussuaq Glacier today (Christoffersen et al., Submitted).

\section{Methods}

The geophysical datasets used in this study were acquired from the RRS James Clark Ross (JCR) in September 2004 using hull-mounted Kongsberg Simrad multibeam swath-bathymetry and Topographic Parametric Sonar (TOPAS) sub-bottom profiler systems. The swath system was a deep-water $12 \mathrm{kHz}$ EM-120 with 191 beams and a $1^{\circ}$ by $1^{\circ}$ beam configuration. Swath data were processed through the removal of anomalous pings and gridded at cell sizes of 30 - 60 m using Kongsberg-Simrad NEPTUNE software. Depth measurements have vertical and horizontal uncertainties of about $1 \mathrm{~m}$ and $5 \mathrm{~m}$, respectively. The TOPAS parametric acoustic profiler has a secondary frequency of $0.5-5 \mathrm{kHz}$. Navigation data were acquired using differential GPS. The ship tracks along which geophysical data were acquired in the Kangerlussuaq fjord-shelf-slope system is shown in Figure 1.

A limited amount of high-resolution swath bathymetry was also obtained from the mouth of Kangerlussuaq Fjord using the Autosub autonomous underwater vehicle (AUV) deployed from the JCR (Dowdeswell et al., 2008a). A Kongsberg Simrad EM-2000 swath-bathymetry system was used, operating at a frequency of $200 \mathrm{kHz}$, with 111 individual beams, an angular coverage of over $120^{\circ}$, and a swath width of up 
to $300 \mathrm{~m}$ (depending on distance from target). Quantitative data on elevation were gridded at a horizontal resolution of $1 \mathrm{~m}$, with RMS errors of better than $10 \mathrm{~cm}$ in the vertical.

\section{Kangerlussuaq Fjord}

\section{Geophysical Observations}

EM-120 swath bathymetry of about $1,500 \mathrm{~km}^{2}$ of the floor of Kangerlussuaq Fjord shows an almost smooth surface, broken by occasional steep-sided pinnacles (Fig. 2A). The fjord forms a relatively uniform, steep-walled basin, deepening systematically down-fjord to a maximum depth of $870 \mathrm{~m}$ near the fjord mouth (Figs. 1D, 2B). Just beyond the fjord mouth, the fjord basin is terminated by a sill that reaches about $500-550 \mathrm{~m}$ in depth (Fig. 2B). A $1.5 \mathrm{~km}$-long swath of bathymetric data, collected by the Autosub EM-2000 system close to the fjord mouth, provides imagery that is an order of magnitude higher in resolution than the hull-mounted EM120. Streamlined lineations and elongate features, orientated sub-parallel to the fjord long-axis are illustrated in Figure 2C. They are found at about $840 \mathrm{~m}$ water depth, in an area about 30-40 $\mathrm{m}$ above the deepest part of the fjord.

TOPAS sub-bottom profiler data from the fjord show acoustically stratified

sediments up to $30-40 \mathrm{~m}$ in thickness, using a sound velocity of $1.5 \mathrm{~km} \mathrm{~s}^{-1}$ (e.g. Elverhøi et al., 1998) (Fig. 2D). The stratified unit is often underlain by an acoustically transparent unit. Similar transparent features also appear as lenses or lobes within the stratified unit. Steep-sided pinnacles protrude through these sedimentary units in a few places, and are characterised by a strong surface return without acoustic penetration.

\section{Interpretation}

The mainly smooth floor of Kangerlussuaq Fjord (Fig. 2A), and the stratified unit that dominates the acoustic stratigraphy (Fig. 2D), are interpreted to be linked to the rain-out of debris from the many icebergs that traverse the fjord (Syvitski et al., 1996), produced from the fast-flowing Kangerlussuaq Glacier at its head (Dwyer, 1995; Rignot and Kanagaratnam, 2006). An acoustically transparent acoustic unit, set within the mainly stratified sediments (Fig. 2D), is interpreted to be produced by debris flows, some of which are derived from slope failure of the steep fjord walls in an environment of relatively rapid sedimentation. The rate of sediment delivery is 
estimated to average $0.7 \mathrm{~cm} \mathrm{yr}^{-1}$ across the whole fjord (Syvitski et al., 1996). Pinnacles protruding through the sediments to the surface, which exhibit no penetration on acoustic records, are of bedrock, which is likely to be part of the Palaeocene basalts that form the East Greenland volcanic province (Henriksen, 2008).

Cores from Kangerlussuaq Fjord sample mainly fine-grained mud interspersed with pebbles (Smith and Andrews, 2000). It is thought that sikussak, or multi-year sea ice, traps many of the calved icebergs within a few kilometres of the glacier terminus and plays an important role in the nature of sedimentation (Syvitski et al., 1996). It has been shown from sequential satellite photographs that icebergs are trapped for at least two years in the sikussak before release (Dwyer, 1995). Basal melting removes much, or all of the few-metres thick high debris-content layer of basal ice (AzetsuScott and Syvitski, 1999), presumably producing heterogeneous diamictic sediment close to the ice front. Sedimentation after iceberg release is then mainly by the rainout of fine-grained low-concentration englacial debris (Dowdeswell, 1986; Syvitski et al., 1996). Turbidity current channels have also been observed in the inner part of Kangerdlusuaq Fjord (Syvitski et al., 2006), in the area that we were unable to access in early September 2006 because of the breakup of the sikussak in August 2006. We record no sea-floor channels in our swath bathymetry of the middle and outer fjord, but turbidite sediments, sampled from cores in the fjord (Syvitski et al., 1996; Smith and Andrews, 2000), appear to contribute up to $40 \%$ of basin fill (Syvitski et al., 1996).

\section{Kangerlussuaq Trough}

\section{Geophysical Observations}

Swath bathymetry of the cross-shelf trough on the Kangerlussuaq margin shows several types of sea-floor landform on the inner and mid shelf, between about $67^{\circ}$ and $68^{\circ} \mathrm{N}$ (Figs. 3, 4A). The geographical distribution and orientation of submarine landforms is mapped in Figure 5A, and each is now described. The majority of linear, streamlined forms include both simple relatively straight lineations up to a few metres high and a few kilometres to tens of kilometres long (Figs. 3C, 4), and blunt-nosed elliptical forms up to $40 \mathrm{~m}$ high and $3000 \mathrm{~m}$ long with smaller elongation ratios (between $3-5: 1$ ) (Fig. 3B, C). Both are positive-relief features. They are usually orientated between NNW-SSE and N-S (Fig. 5). The blunt end of the elliptical 
landforms always faces northward, and the streamlined 'tail' is orientated southwards (Fig. 3B, C). Crescentic overdeepenings, a few hundred metres in length and up to 35 $\mathrm{m}$ in depth, also occur in one area in association with the streamlined landforms (Fig. 3C). The crescentic features have a similar orientation to the linear landforms, with the crescent 'tails' facing southwards. A few channel-like features are also present on the inner shelf (Fig 3B). They are usually sinuous and up to $10 \mathrm{~m}$ deep and $10 \mathrm{~km}$ long, with long profiles that have both positive and negative slopes. Irregularly orientated grooves occur in shallower areas of the trough and approaching the banks to either side of the trough (Fig. 3A).

On the outer shelf, south of approximately $67^{\circ} \mathrm{N}$, there are just a few poorly defined linear features orientated N-S (Fig. 4). This region, which is shallower than the inner shelf, is dominated by large numbers of irregular grooves that often cross-cut one another (Figs. 4B, 6D). The irregular grooves are up to about $15 \mathrm{~m}$ deep, $50 \mathrm{~m}$ wide and often hundreds of metres long; they form depressions in the general sea floor and are sometimes associated with raised berms of a metre or two in height at their margins. Acoustically, there is little prenetration beneath a very irregular and sometimes diffuse surface reflector (Fig. 5B, Reflector B3).

Several acoustic facies and reflectors are identified and mapped on the Kangerlussuaq margin (Fig. 5). An example of each acoustic unit and reflector is given in Figure 5B. The acoustically stratified unit (Facies S) is restricted to Kangerlussuaq Fjord and its mouth (Fig. 2D). Acoustically transparent to semitransparent lobes (Facies L1 and L2) are observed in the fjord and on the slope offshore of the shelf edge, respectively (Fig. 6E). The other acoustic units, a semitransparent to stratified drape (Facies D), a strong and impenetrable surface reflector (Reflector B1) and a transparent unit (Facies T) usually underlain by a strong basal reflector (Reflector B2), all occur on the shelf; however, only Facies T and Reflector B2, together with a highly irregular, diffuse surface reflector (Reflector B3), are present on the outer shelf (Fig. 5A).

Most of the linear, streamlined landforms on the inner shelf are associated with Facies T, the semi-transparent unit which is underlain at a depth of typically a few metres by a strong and impenetrable basal reflector (B2). The landforms appear to be formed as part of this acoustic unit (Fig. 6B, C). In one case, in a zone about $7 \mathrm{~km}$ wide on the inner shelf, linear features with amplitudes of up to $80 \mathrm{~m}$ (Fig. 3A) are 
linked to a strong sea-floor reflector (B1) that allows no acoustic penetration (Fig. 6A). Occasionally, these linear features are draped by a thin acoustically laminated that reaches just 1 to $2 \mathrm{~m}$ at most in thickness. These linear features are orientated WNW-ENE, in contrast to the more N-S orientation of the streamlined features set within the acoustically semi-transparent unit which is itself underlain by a strong basal reflector.

\section{Interpretation}

The blunt-nosed and linear streamlined landforms in Kangerlussuaq Trough (Figs. 3B-C, 4), usually underlain by acoustical semi-transparent material (Facies T) (Fig. $6 \mathrm{~B}, \mathrm{C})$, are interpreted as drumlins and glacial lineations produced at the sedimentary bed of an ice sheet that was present in the trough at the LGM. The strong, continuous reflector (B2) at the base of acoustic Facies $\mathrm{T}$ is similar in appearance and position to that observed and cored on other high-latitude shelves, where a stiff overconsolidated till is overlain by deformation till of low shear strength whose flow facilitated past ice motion (Dowdeswell et al., 2004; Ó Cofaigh et al., 2005a, 2005b, 2007; Evans et al., 2006, 2009). These elongate and streamlined landforms are produced beneath ice sheets and have been observed forming at the bed of modern ice streams (King et al., 2009). They have been used by many previous workers to reconstruct the direction of past ice flow (e.g. Shipp et al., 1999; Canals et al., 2000; Ottesen et al., 2005; Ó Cofaigh et al., 2005a; Evans et al., 2006; Andreassen et al., 2008; Dowdeswell et al., 2009).

Some drumlins have crescentic overdeepenings on their upstream sides (Fig. 3C). These features have been interpreted to indicate water flow at the ice-bed interface around the up-ice or stoss face of drumlins (Wellner et al., 2001; Ó Cofaigh et al., 2002). There is also limited evidence of sinuous channels within a kilometre or so of some drumlins (Fig. 3B), suggesting that past subglacial water flow in this part of the trough may have formed a coherent system. The up-and-down long profile of the channels implies that water flow was within a pressurized subglacial system (Rothlisberger, 1972). South of $67^{\circ} 15^{\prime} \mathrm{N}$, drumlins, together with crescentic overdeepenings and channels, are not observed. Instead, relatively straight but subdued linear bedforms are present (Fig. 4), again set in the surface of a sedimentary substrate (Fig. 6C). Any subglacial water flow on the outer shelf was therefore through the sedimentary substrate itself, rather than in a channel system; a situation to 
that found in several outer-shelf troughs in Antarctica (e.g. Wellner et al., 2001; Ó Cofaigh et al., 2002, 2005a; Evans et al., 2006).

A $7 \mathrm{~km}$-wide set of linear landforms between $67^{\circ} 53^{\prime} \mathrm{N}$ and $67^{\circ} 48^{\prime} \mathrm{N}$ (Fig. $3 \mathrm{~A}$ ) has very different acoustic characteristics to the sedimentary features described above. TOPAS records show a strong and acoustically impenetrable surface reflector (B1, Figure $5 \mathrm{~B}$ ) that is draped in some places by a thin layer of sediment that is sometimes laminated acoustically (Fig. 6A). The amplitude of these linear landforms is typically between 40 and $80 \mathrm{~m}$ (Figs. 3A, 6A), in contrast to the few metres height of the streamlined sedimentary features described above (Fig. 6B). These features are interpreted as bedrock ridges, orientated in a WNW-ESE direction, that sometimes have a thin drape of Holocene hemipelagic sediment on their less steep faces. This interpretation is confirmed by sleeve-gun records from the area, where the presence of localised scarps and dykes is inferred (Stein, 1996). These bedrock landforms are, therefore, probably related to the regional bedrock geology of East Greenland rather than to Quaternary glacial processes in Kangerlussuaq Trough. Much of the bedrock on the inner shelf of East Greenland is made up of Palaeocene basalts of the East Greenland volcanic province, with volcanism beginning about 62 million years ago (Henriksen, 2008).

The irregular, cross-cutting grooves on much of the shelf at water depths of less than about $\sim 450 \mathrm{~m}$ (Figs. 3A, 6D) are interpreted straightforwardly as sea-floor scours produced by the ploughing action of grounded iceberg keels (Woodworth-Lynas et al., 1991). They are particularly prominent on the sill separating the fjord and inner shelf (Fig. 3A), and on the outer shelf (Fig. 4), and are almost ubiquitous close to the Kangerlussuaq shelf edge (Fig. 6D). Ploughing by iceberg keels reworks shelf stratigraphy and destroys any pre-existing glacial sedimentary landforms at water depths less than about $450 \mathrm{~m}$ on the Kangerlussaq margin.

Iceberg scours are very common on the Greenland continental shelf (Brett and Zarudzki, 1979; Dowdeswell et al., 1993; Syvitski et al., 2001), and on high-latitude shelves in general. Deep-keeled icebergs are usually derived from the margins of fastflowing ice streams and ice-sheet outlet glaciers (Dowdeswell and Bamber, 2007), and icebergs with keel depths in excess of $450 \mathrm{~m}$ are produced from both Kangerlussuaq Glacier and Daugaard-Jensen Glacier in East Greenland today (Dowdeswell et al., 1992; Syvitski et al., 1996). However, Syvitski et al. (2001) suggest that modern icebergs with keels greater than 300-400 m are prevented from 
entering much of the Kangerlussuaq Trough by topographic barriers and that Holocene hemipelagic sedimentation is slowly burying relict scour marks within the trough.

\section{Kangerlussuaq Shelf Edge and Slope}

\section{Geophysical Observations}

Swath bathymetry covering about $35,000 \mathrm{~km}^{2}$ of the outermost continental shelf and the slope offshore of Kangerlussuaq Trough is centred on $65^{\circ} 20^{\prime} \mathrm{N}, 30^{\circ} 40^{\prime} \mathrm{W}$ (Fig. 1A). The shelf edge is typically the shallowest part of the continental shelf along the axis of Kangerlussuaq Trough (Fig. 6D), excluding the banks to either side of the trough (Syvitski et al., 2001). The sea floor close to the shelf edge has a very rough appearance on sub-bottom profiler records (Fig. 6D; reflector B3 in Fig. 5B), and swath bathymetry on the outer shelf shows the presence of many irregular linear depressions, up to about $15 \mathrm{~m}$ deep, $50 \mathrm{~m}$ wide and often hundreds of metres long (Fig. 4).

Beyond the shelf break, there are very few features present on swath bathymetry of the 1.8 to $2^{\circ}$ continental slope. Sub-bottom profiler records, however, reveal the presence of a number of semi-transparent lobes on the slope (Fig. 6E; acoustic facies L2 in Fig. 5B). At water depths of about 1,350 $\mathrm{m}$ on the continental slope, sediments with acoustically wavy sub-parallel reflectors at least $25 \mathrm{~m}$ thick have built up (Fig. $6 \mathrm{~F})$.

\section{Interpretation}

The irregular, cross-cutting linear features on the outermost Kangerlussuaq shelf (Fig. 6D) are produced by the scouring action of deep-keeled icebergs, in common with similar features covering much of the Greenland shelf above about $500 \mathrm{~m}$ in water depth (Brett and Zarudzki, 1979; Dowdeswell et al., 1993; Syvitski et al., 2001). These cross-cutting scour marks have been produced not only during deglaciation from the LGM, but may be produced occasionally today by deep-keeled icebergs calved, for example, from the fast-flowing outlet glaciers feeding icebergs into the East Greenland Current from further north in East Greenland (Dowdeswell et al., 1992; Rignot and Kanagaratnam, 2006). 
Beyond the shelf break, the portion of the continental slope imaged by swath bathymetry shows limited morphological variability, with little evidence of upperslope gullies or channels. However, this may be in part a function of the relatively small area of swath coverage offshore of Kangerlussuaq Trough (Fig. 1), together with the observation of hard-ground composed of gravel and sand produced by current winnowing on the upper slope (Mienert et al., 1992; Syvitski et al., 2001). Further north in East Greenland, extensive turbidite channel systems are found on the mid-slope, continuing to abyssal depths in the 250,000 $\mathrm{km}^{2}$ Greenland Basin (Mienert et al., 1993; Dowdeswell et al., 2002; Ó Cofaigh et al., 2004; Wilken and Mienert, 2006).

Sub-bottom profiler records identify several transparent lobate features on the Kangerlussuaq slope (Fig. 6E), which are interpreted as debris flows. Similar lobate features were reported by Stein (1996) from seismic records at water depths of about 1,800 to $2,000 \mathrm{~m}$ on the slope. Radiocarbon dates on core material immediately above sediments interpreted as possible debris flows on the Kangerlussuaq slope suggest that mass wasting was probably active at the LGM (Stein, 1996; Andrews et al., 1998; Dunhill, 2005).

Debris flows are a characteristic part of the sedimentary architecture of troughmouth fans around the Norwegian-Greenland Sea (Aksu and Hiscott, 1992; Dowdeswell et al., 1996; King et al., 1996; Vorren et al., 1998; Taylor et al., 2002), and are made up of diamictic material that is thought to be derived largely from the delivery of glacially eroded sediment in fast-flowing ice streams (Laberg and Vorren, 1995; Elverhøi et al., 1997). Huge fans, such as the Bear Island, Scoresby Sund and Belgica fans (Dowdeswell et al., 1997; Vorren and Laberg, 1997; Dowdeswell et al., 2008b), are built up over successive glaciations as ice advanced across high-latitude continental shelves, sometimes to the shelf edge, and the upper slope became the fullglacial focus for rapid sedimentation (Dowdeswell et al., 1996, 1998; Vorren et al., 1998; Ó Cofaigh et al., 2003). The outward-convex contours of the shelf edge and slope beyond Kangerlussuaq Trough (Fig. 1B) suggest a major sedimentary depocentre; a trough-mouth fan similar to those described above. Seismic data confirm that much of the Kangerlussuaq continental shelf, south of about $67^{\circ} 40^{\prime} \mathrm{N}$, is a prograding sedimentary wedge (Larsen, 1984; Stein, 1996); however, part of this material may be pre-glacial marine onlap deposits and fluvio-deltaic sediments of 
Eocene to Oligocene age, overlain by Quaternary glacial sediments (Larsen, 1984, 1994). Finally, in common with much of the East Greenland continental slope (Wilken and Mienert, 2006), no major slide scars or run-out areas were observed on our swath coverage of the Kangerlussuaq slope. Finally, sediments with wavy internal reflectors at the base of the Kangerlussuaq slope (Fig. 6F) are interpreted as contourites (e.g. Faugeres and Stow, 1993), produced by the strong, geostrophic East Greenland Current.

\section{Discussion: Ice-Sheet Extent and Flow on the Kangerlussuaq Margin}

A number of submarine landforms that are produced subglacially have been described and interpreted above. The distribution of streamlined sedimentary bedforms, including lineations, drumlins, and subglacial meltwater indicators in the form of crescentic overdeepenings and channels, demonstrates that the Greenland Ice Sheet extended throughout Kangerlussuaq Fjord and onto the continental shelf beyond into Kangerlussuaq Trough (Fig. 5A). The furthest across the shelf that streamlined linear features have been identified is at about $66^{\circ} \mathrm{N}$, approximately $220 \mathrm{~km}$ from the fjord mouth (Figs. 1A, 4B, 5A). Beyond this point, the shallowing outer shelf is scoured by iceberg keels to the point that any other landforms produced during ice advance would be removed. Thus, we can state that ice reached at least $200 \mathrm{~km}$ across the shelf in Kangerlussuaq Trough at the LGM. Mienert et al. (1992) reported a stiff diamict in a core taken in 299 m of water to the east of Kangerlussuaq Trough at $66^{\circ} 28^{\prime} \mathrm{N}, 29^{\circ} 41^{\prime} \mathrm{W}$, which also indicates the presence of grounded ice on the Kangerlussuaq shelf.

Chronological evidence from Kangerlussuaq Trough indicates that the submarine landforms were produced at the LGM (Mienert et al., 1992; Jennings et al., 2002, 2006). Radiocarbon dates on core material from previous investigations suggest that ice retreat from the outer shelf began shortly after about 17,000 yr ago, reaching the inner shelf by about 15,000 yr ago and the present coast at between 13,600 to 11,500 years ago (Mienert et al., 1992; Jennings et al., 2002, 2006). Ice extending out onto the continental shelf, and perhaps even to the shelf edge, at the LGM has been reported from several other parts of the East Greenland margin recently (Evans et al., 2002, 2009), and is also consistent with evidence of ice filling coastal valleys in South-East Greenland at that time (Roberts et al., 2008). 
The orientation of streamlined landforms is consistent with ice flow sub-parallel to the axis of Kangerlussuaq Trough. Sedimentary lineations, drumlins and crescentic overdeepenings are all orientated between NNW-SSE and N-S (Figs. 3B-C, 4, 5A). In addition, both blunt-nosed drumlins, and the crescentic overdeepenings that are often associated with them, provide the full sense of ice-flow direction. The blunt faces of drumlins always face towards the direction from which ice flows, and the 'wings' of the overdeepenings orientate with ice flow (Benn and Evans, 1998). We know, therefore, that ice flowed generally from north to south down Kangerlussuaq Trough. This is clearly consistent with flow from the interior of the Greenland Ice Sheet, through the deep channel of Kangerlussuaq Fjord and then across the shelf in the trough. Although ice is also likely to have been present on the shallower banks either side of Kangerlussuaq Trough, any submarine-landform evidence of this has been removed by iceberg scouring (Syvitksi et al., 2001). Indeed, the presence of landforms indicative of subglacial meltwater, and the implication that deformation till is present in the trough as acoustic facies T, both support the notion that warm ice was present and that motion was by both internal ice deformation and basal processes (e.g. Dowdeswell et al., 2004; Ó Cofaigh et al., 2005, 2007).

Some inferences about the nature of ice-sheet retreat across the shelf at the end of the LGM can also be made from the subglacial landform record in outer Kangerlussuaq Trough. There is little evidence for sedimentary depocentres, known as grounding-zone wedges, indicative of ice-sheet still-stands during retreat (e.g. Evans et al., 2005; McMullen et al., 2006; Mosola and Anderson, 2006). Neither are there the relatively small sets of sedimentary ridges that form at the retreating margin of a grounded ice sheet (e.g. Shipp et al., 2002; Dowdeswell et al., 2008c; Ottesen and Dowdeswell, 2009). This is consistent with the observation that the East Greenland shelf deepens towards the coast, and ice would therefore have been retreating into deepening water with the exception of the inner-trough shelf (Fig. 1D). Retreat into deeper waters tends to increase the rate of iceberg calving from a retreating ice sheet, with the implication that the ice in Kangerlussuaq Trough probably retreated rapidly back at least as far as the inner shelf sill, where there is seismic evidence of a moraine (Stein, 1996), and later through the deep outer fjord, during deglaciation (Dowdeswell et al., 2008c). This is supported by chronological work on cores from the trough suggesting that retreat from the outer Kangerlussuaq shelf took place from about about $17,000 \mathrm{yr}$ ago, reaching the inner shelf by about 15,000 yr ago and the outer 
coast of Greenland by between 13,600 and 11,500 years ago (Jennings et al., 2002, 2006).

\section{Conclusions}

- Kangerlussuaq Fjord is a relatively uniform, steep-walled basin, whose floor has an almost smooth surface, broken by occasional protruding bedrock pinnacles (Fig. 2). Debris is supplied mainly from icebergs produced from the fast-flowing Kangerlussuaq Glacier. Multi-year sea ice, sikussak, traps many calved icebergs close to the glacier terminus where basal melting removes the bulk of debris-rich basal ice. Sedimentation after iceberg release from sikussak is mainly by rain-out of fine-grained englacial debris (Syvitski et al., 1996; Smith and Andrews, 2001).

- Streamlined glacial lineations and drumlins were produced at the sedimentary bed of an ice sheet that advanced into Kangerlussuaq Trough at the LGM (Figs. 3, 4). They form the upper surface of an acoustically transparent unit, with a strong basal reflector (Fig. 6B), which is probably low shear-strength till whose deformation facilitated ice motion.

- Bedrock channels and crescentic overdeepenings indicate subglacial meltwater flow on the inner shelf (Fig. 3B, C), implying the presence of warm-based ice and free water beneath this part of the LGM ice sheet which allowed motion by both internal ice deformation and basal processes.

- Cross-cutting iceberg scour marks, formed by the ploughing of grounded iceberg keels, dominate the outermost Kangerlussuaq shelf (Figs. 4, 6D), and the surrounding banks (Syvitski et al., 2001). They were probably produced not only during deglaciation, but also occasionally through the Holocene by deep-keeled icebergs calved from fast-flowing outlet glaciers further north in East Greenland (Dowdeswell et al., 1992).

- The outward-convex contours of the shelf edge and slope beyond Kangerlussuaq Trough suggest an ice-stream influenced high-latitude fan architecture (Fig. 1). Sub-bottom profiler records show a number of semi-transparent debris flows (Fig. $6 \mathrm{E})$, which are a characteristic part of many ice-sheet fed trough-mouth fans (e.g. Vorren et al., 1998).

- The distribution of streamlined subglacial landforms (Fig. 5A) demonstrates that the Greenland Ice Sheet extended throughout Kangerlussuaq Fjord and reached at 
least $200 \mathrm{~km}$ across the shelf in Kangerlussuaq Trough at the LGM. The orientation of streamlined landforms (Fig. 5A) is consistent with flow from the interior of the Greenland Ice Sheet sub-parallel to the axis of Kangerlussuaq Trough.

- There is little evidence for sedimentary depocentres (grounding-zone wedges, transverse sedimentary ridges) in Kangerlussuaq Trough, implying that ice probably retreated rapidly at least as far as the inner shelf sill, and later through the deep outer fjord, during deglaciation (Dowdeswell et al., 2008).

\section{Acknowledgements}

Work from the RRS James Clark Ross was funded by UK Natural Environment Research Council Grant NER/T/S/2000/00986 to JAD as part of the 'Autosub under Ice' Thematic Programme. We thank Anne Jennings and Paul Knutz for useful comments on the manuscript.

\section{References}

Aksu, A.E. and Hiscott, R.N., 1992. Shingled Quaternary debris flow lenses on the north-east Newfoundland slope. Sedimentology, 39, 193-206.

Anderson, J.B., Shipp, S.S., Lowe, A.L., Wellner, J.S. and Mosola, A.B., 2002. The Antarctic Ice Sheet during the Last Glacial Maximum and its subsequent retreat history: a review. Quaternary Science Reviews, 21, 49-70.

Andreassen, K., Laberg, J.S. and Vorren, T.O., 2008. Seafloor geomorphology of the SW Barents Sea and its glaci-dynamic implications. Geomorphology, 97, 157-177.

Andrews, J.T., Jennings, A.E., Cooper, T., Williams, K.M. and Mienert, J., 1996. Late Quaternary sedimentation along a fjord to shelf (trough) transect, East Greenland $\left(68^{\circ} \mathrm{N}\right)$. In Andrews, J.T., Austin, W.E.N., Bergsten, H. and Jennings A.E., (Eds.), Late Quaternary Paleoceanography of the North Atlantic Margins. Geological Society, London, Special Publication, 111, 153-166.

Andrews, J.T., Cooper, T.A., Jennings, A.E., Stein, A.B. and Erlenkeuser, H., 1998. Late Quaternary iceberg-rafted detritus events on the Denmark Strait/Southeast Greenland continental slope $\left(\sim 65^{\circ} \mathrm{N}\right)$ : Related to North Atlantic Heinrich Events? Marine Geology, 149, 211-228. 
Azetsu-Scott, K. and Syvitski, J.P.M., 1999. How melting icebergs influence particle distribution in the water column. Journal of Geophysical Research, 104, 5321-5328.

Benn, D.I. and Evans, D.J.A., 1998. Glaciers and Glaciation. London, Arnold, 734 pp.

Brett, C.P. and Zarudzki, E.F.K., 1979. Project Westmar: a shallow marine geophysical survey on the West Greenland continental shelf. Greenland Geological Survey, Report, 87, $27 \mathrm{pp}$.

Canals, M., Urgeles, R., Calafat, A.M., 2000. Deep sea floor evidence of past ice streams off the Antarctic Peninsula. Geology, 28, 31-34.

Christoffersen, P., Heywood, K.J., Joughin, I., Dowdeswell, J.A., Syvitski, J.P.M., Benham, T.J., Mugford, R.I. and Luckman, A. Ocean impact on East Greenland outlet glaciers: 2. Ice flow and water mass change in Kangerlussuaq Fjord. Submitted to Journal of Geophysical Research.

Dowdeswell, J.A., 1986. The distribution and character of sediments in a tidewater glacier, southern Baffin Island, N.W.T., Canada. Arctic and Alpine Research, 18, 45-56.

Dowdeswell, J.A. and Bamber, J.L., 2007. Keel depths of modern Antarctic icebergs and implications for sea-floor scouring in the geological record. Marine Geology, 243, 120131.

Dowdeswell, J.A. Whittington, R.J., and Hodgkins, R., 1992. The sizes, frequencies and freeboards of East Greenland icebergs observed using ship radar and sextant. Journal of Geophysical Research, 97, 3515-3528.

Dowdeswell, J.A., Villinger, H., Whittington, R.J., and Marienfeld, P., 1993. Iceberg scouring in Scoresby Sund and on the East Greenland Continental Shelf. Marine Geology, 111, 3753.

Dowdeswell, J.A., Whittington, R.J. and Marienfeld, P., 1994. The origin of massive diamicton facies by iceberg rafting and scouring, Scoresby Sund, East Greenland. Sedimentology, 41, 21-35.

Dowdeswell, J.A., Kenyon, N., Elverhøi, A., Laberg, J.S., Mienert, J. and Siegert, M.J., 1996. Large-scale sedimentation on the glacier-influenced Polar North Atlantic margins: longrange side-scan sonar evidence. Geophysical Research Letters, 23, 3535-3538.

Dowdeswell, J.A., Kenyon, N.H. and Laberg, J.S. 1997. The glacier-influenced Scoresby Sund Fan, East Greenland continental margin: evidence from GLORIA and $3.5 \mathrm{kHz}$ records. Marine Geology, 143, 207-221.

Dowdeswell, J.A., Elverhøi, A. and Spielhagen, R., 1998. Glacimarine sedimentary processes and facies on the Polar North Atlantic margins. Quaternary Science Reviews, 17, 243272. 
Dowdeswell, J.A., Whittington, R.J., Jennings, A.E., Andrews, J.T., Mackensen, A. and Marienfeld, P., 2000. An origin for laminated glacimarine sediments through sea-ice build-up and suppressed iceberg rafting. Sedimentology, 47, 557-576.

Dowdeswell, J.A., Ó Cofaigh, C., Taylor, J., Kenyon, N.H., Mienert, J. and Wilken, M., 2002. On the architecture of high-latitude continental margins: the influence of ice-sheet and sea-ice processes in the Polar North Atlantic. In Dowdeswell, J.A. and Ó Cofaigh, C., (Eds.), Glacier-Influenced Sedimentation on High-Latitude Continental Margins. Geological Society, London, Special Publication, 203, 33-54.

Dowdeswell, J.A., Evans, J., Mugford, R., Griffiths, G., McPhail, S., Millard, N., Stevenson, P., Brandon, M.A., Banks, C., Heywood, K.J., Price, M.R., Dodd, P.A., Jenkins, A., Nicholls, K.W., Hayes, D., Abrahamsen, E.P., Tyler, P., Bett, B., Jones, D., Wadhams, P., Wilkinson, J.P., Stansfield, K. and Ackley, S., 2008a. Autonomous underwater vehicles (AUVs) and investigations of the ice-ocean interface in Antarctic and Arctic waters. Journal of Glaciology, 54, 661-672.

Dowdeswell, J.A., Ó Cofaigh, C., Noormets, R., Larter, R.D., Hillenbrand, C.-D., Benetti, S., Evans, J. and Pudsey, C.J., 2008b. A major trough-mouth fan on the continental margin of the Bellingshausen Sea, West Antarctica: Belgica Fan. Marine Geology, 252, 129-140.

Dowdeswell, J.A., Ottesen, D., Evans, J., Ó Cofaigh, C. and Anderson, J.B., 2008c. Submarine glacial landforms and rates of ice-stream collapse. Geology, 36, 819-822.

Dunhill, G., 2005. Iceland and Greenland margins: A comparison of depositional processes under different glaciologic and oceanographic settings. Ph.D. Thesis, Geological Sciences, University of Colorado, Boulder, $243 \mathrm{pp}$.

Dwyer, J.L., 1995. Mapping tide-water glacier dynamics in East Greenland using Landsat data. Journal of Glaciology, 41, 584-595.

Elverhøi, A., Norem, H., Andersen, E.S., Dowdeswell, J.A., Fossen, I., Haflidason, H., Kenyon, N.H., Laberg, J.S., King, E.L., Sejrup, H.P., Solheim, A., and Vorren, T.O., 1997. On the origin and flow behavior of submarine slides on deep-sea fans along the Norwegian-Barents Sea continental margin. Geo-Marine Letters, 17, 119-125.

Elverhøi, A., Hooke, R.LeB. and Solheim, A., 1998. Late Cenozoic erosion and sediment yield from the Svalbard-Barents Sea region: implications for understanding erosion of glacierized basins. Quaternary Science Reviews, 17, 209-241.

Evans, J., Dowdeswell, J.A., Grobe, H., Niessen, F., Stein, R., Hubberten, H.-W., and Whittington, R.J., 2002. Late Quaternary sedimentation in Kejser Franz Joseph Fjord and the continental margin of East Greenland. In Dowdeswell, J.A. and Ó Cofaigh, C., (Editors), Glacier-Influenced Sedimentation on High-Latitude Continental Margins, Geological Society, London, Special Publication, 203, 149-179. 
Evans, J., Pudsey, C.J., Ó Cofaigh, C., Morris, P.W. and Domack, E.W., 2005. Late Quaternary glacial history, dynamics and sedimentation of the eastern margin of the Antarctic Peninsula Ice Sheet. Quaternary Science Reviews, 24, 741-774.

Evans, J., Dowdeswell, J.A., Ó Cofaigh, C., Benham, T.J. and Anderson, J.B., 2006. Extent and dynamics of the West Antarctic Ice Sheet on the outer continental shelf of Pine Island Bay, Amundsen Sea, during the last deglaciation. Marine Geology, 230, 53-72.

Evans, J., Ó Cofaigh, C., Dowdeswell, J.A. and Wadhams, P., 2009. Marine geophysical evidence for former expansion and flow of the Greenland Ice Sheet across the north-east Greenland continental shelf. Journal of Quaternary Science, 24, 279-293.

Faugeres, J.C. and Stow, D.A.V., 1993. Bottom-current controlled sedimentation: a synthesis of the contourite problem. Sedimentary Geology, 82, 287-297.

Funder, S. and Hansen, L., 1996. The Greenland ice sheet - a model for its culmination and decay during and after the Last Glacial Maximum. Bulletin of the Geological Society of Denmark, 42, 137-152.

Funder, S., Hjort, C., Landvik, J., Nam, S.I., Reeh, N. and Stein, R., 1998. History of a stable ice margin - East Greenland during the Middle and Upper Pleistocene. Quaternary Science Reviews, 17, 77-125.

Henriksen, N., 2008. Geological History of Greenland. GEUS, Denmark, 272 pp.

Howat, I.M., Joughin, I. and Scambos, T.A., 2007. Rapid changes in ice discharge from Greenland outlet glaciers. Science, 315, 1559-1561.

Jennings, A.E., Grönvold, K., Hilberman, R., Smith, M. and Hald, M., 2002. High-resolution study of Icelandic tephras in the Kangerlussuaq Trough, southeast Greenland, during the last deglaciation. Journal of Quaternary Science, 17, 747-757.

Jennings, A.E., Hald, M., Smith, M and Andrews, J.T., 2006. Freshwater forcing from the Greenland Ice Sheet during the Younger Dryas: evidence from southeastern Greenland shelf cores. Quaternary Science Reviews, 25, 282-298.

Joughin, I. et al., 2008. Ice-front variation and tidewater behavior on Helheim and Kangerdlugssuaq Glaciers, Greenland. Journal of Geophysical Research, 113.

King, E.C., Hindmarsh, R.C.A. and Stokes, C.R., 2009. Formation of mega-scale glacial lineations observed beneath a West Antarctic ice stream. Nature Geoscience, 2, 585-588.

King, E.L., Sejrup, H.P., Haflidason, H., Elverhøi, A. and Aarseth, I., 1996. Quaternary seismic stratigraphy of the North Sea Fan: glacially-fed gravity flow aprons, hemipelagic sediments, and large submarine slides. Marine Geology, 130, 293-315.

Laberg, J.S. \& Vorren, T.O. 1995. Late Weichselian submarine debris flow deposits on the Bear Island Trough Mouth Fan. Marine Geology, 127, 45-72. 
Larsen, H.C., 1984. Geology of the East Greenland shelf. In Spencer, A.M. and Trotman, P., (Eds.), Petroleum Geology of the North European Margin, 329-339. Norwegian Petroleum Society, Stavanger.

Larsen, H.C., Saunders, A.D., Clift, P.D., Beget, J., Wei, W. And Spezzaferri, S., 1994. Seven million years of glaciation in Greenland. Science, 264, 952-955.

Luckman, A., Murray, T., de Lange, R. and Hanna, E., 2006. Rapid and synchronous icedynamic changes in East Greenland. Geophysical Research Letters, 33, L03503.

McMullen, K., Domack, E., Leventer, A., Olson, C., Dunbar, R. and Brachfeld, S., 2006. Glacial morphology and sediment formation in the Mertz Trough, East Antarctica. Palaeogeography, Palaeoclimatology, Palaeoecology, 231, 169-180.

Mienert, J., Andrews, J.T. and Milliman, J.D., 1992. The East Greenland continental margin $\left(65^{\circ}\right)$ : Changes in seafloor properties and ocean circulation. Marine Geology, 106, $217-$ 238.

Mienert, J., Kenyon, N.H., Thiede, J. and Hollender, F.-J., 1993. Polar continental margins: studies off East Greenland. EOS, Transactions of the American Geophysical Union, 74, $225,231,234,236$.

Mosola, A.B. and Anderson, J.B., 2006. Expansion and rapid retreat of the West Antarctic Ice Sheet in eastern Ross Sea: possible consequence of over-extended ice streams? Quaternary Science Reviews, 25, 2177-2196.

Ó Cofaigh, C., Pudsey, C.J., Dowdeswell, J.A. and Morris, P., 2002. Evolution of subglacial bedforms along a paleo-ice stream, Antarctic Peninsula continental shelf. Geophysical Research Letters, 29, doi: 10.1029/2001. GL014488.

Ó Cofaigh, C., Taylor, J., Dowdeswell, J.A. and Pudsey, C.J., 2003. Palaeo-ice streams, trough mouth fans and high-latitude continental slope sedimentation. Boreas, 32, 37-55.

Ó Cofaigh, C., Dowdeswell, J.A., Kenyon, N.H., Evans, J., Taylor, J., Mienert, J. and Wilken, M., 2004. Timing and significance of glacially-influenced mass wasting in the submarine channels of the Greenland Basin. Marine Geology, 207, 39-54.

Ó Cofaigh, C., Larter, R.D., Dowdeswell, J.A., Hillenbrand, C.D., Pudsey, C.J., Evans, J. and Morris, P., 2005a. Flow of the West Antarctic Ice Sheet on the continental margin of the Bellingshausen Sea at the Last Glacial Maximum. Journal of Geophysical Research, 110, B11103, doi.10.1029/2005JB003619.

Ó Cofaigh, C., Dowdeswell, J.A., Allen, C.S., Hiemstra, J., Pudsey, C.J., Evans, J. and Evans, D.J.A., 2005b. Flow dynamics and till genesis associated with a marine-based Antarctic palaeo-ice stream. Quaternary Science Reviews, 24, 709-740.

Ó Cofaigh, C., Evans, J., Dowdeswell, J.A. and Larter, R.D., 2007. Till characteristics, genesis and transport beneath Antarctic paleo-ice streams. Journal of Geophysical Research, 112, F03006, doi:101029/2006JF000606 
Ottesen, D., Dowdeswell, J.A. and Rise, L., 2005. Submarine landforms and the reconstruction of fast-flowing ice streams within a large Quaternary ice sheet: the 2500 $\mathrm{km}$-long Norwegian-Svalbard margin $\left(57^{\circ}-80^{\circ} \mathrm{N}\right)$. Bulletin of the Geological Society of America, 117, 1033-1050.

Ottesen, D. and Dowdeswell, J.A., 2009. An inter-ice stream glaciated margin: submarine landforms and a geomorphic model based on marine-geophysical data from Svalbard. Bulletin of the Geological Society of America, 121, 1647-1665.

Reeh, N., 1985. Greenland Ice-Sheet mass balance and sea-level change. In Glaciers, Ice Sheets and Sea Level: Effect of a $\mathrm{CO}_{2}$-induced Climatic Change. Report DOE/EV/602351, 155-171, U.S. Department of Energy, Washington D.C.

Reeh, N., Mayer, C., Miller, H., Thomsen, H.H. and Weidick, A., 1999. Present and past climate control on fjord glaciations in Greenland: implications for IRD-deposition in the sea. Geophysical Research Letters, 26, 1039-1042

Rignot, E. and Kanagaratnam, P., 2006. Changes in the velocity structure of the Greenland Ice Sheet. Science, 311, 986-988.

Roberts, D.H., Long, A.J., Schnabel, C., Freeman, S. and Simpson, M.J.R., 2008. The deglacial history of southeast sector of the Greenland Ice Sheet during the last Glacial Maximum. Quaternary Science Reviews, 27, 1505-1516.

Röthlisberger, H., 1972. Water pressure in intra- and sub-glacial channels. Journal of Glaciology, 11, 177-203.

Shipp, S.S., Anderson, J.B., and Domack, E.W., 1999. Late Pleistocene-Holocene retreat of the West Antarctic Ice-Sheet system in the Ross Sea: Part 1 - Geophysical results. Geological Society of America Bulletin, 111, 1486-1516.

Shipp, S.S., Wellner, J.S. and Anderson, J.B., 2002. Retreat signature of a polar ice stream: sub-glacial geomorphic features and sediments from the Ross Sea, Antarctica. In Dowdeswell, J.A. and Ó Cofaigh, C., (Eds.), Glacier-Influenced Sedimentation on HighLatitude Continental Margins, Geological Society, London, Special Publication, 203, 277 304.

Smith, L.M. and Andrews, J.T., 2001. Sediment characteristics in iceberg dominated fjords, Kangerlussuaq region, East Greenland. Sedimentary Geology, 130, 11-25.

Stein, A.B., 1996. Seismic stratigraphy and seafloor morphology of the Kangerlugssuaq region, East Greenland: Evidence for glaciations to the continental shelf break during the Late Weichselian and earlier. M.Sc. Thesis, University of Colorado, Boulder, 293 pp.

Syvitski, J.P.M., Andrews, J.T. and Dowdeswell, J.A., 1996. Sediment deposition in an iceberg-dominated glacimarine environment, East Greenland: basin fill implications. Global and Planetary Change, 12, 251-270. 
Syvitski, J.P.M., Stein, A.B., and Andrews, J.T., 2001. Icebergs and the sea floor of the East Greenland (Kangerlussuaq) continental margin. Arctic, Antarctic, and Alpine Research, 33, 52-61.

Taylor, J., Dowdeswell, J.A., Kenyon, N.H. and Ó Cofaigh, C., 2002. Late Quaternary architecture of trough-mouth fans: debris flows and suspended sediments on the Norwegian margin. In Dowdeswell, J.A. and Ó Cofaigh, C., (Eds.), Glacier-Influenced Sedimentation on High-Latitude Continental Margins, Geological Society, London, Special Publication, 203, 55-71.

Vorren, T.O. and Laberg, J.S., 1997. Trough mouth fans - palaeoclimate and ice-sheet monitors. Quaternary Science Reviews, 16, 865-881.

Vorren, T.O., Laberg, J.S., Blaume, F., Dowdeswell, J.A., Kenyon, N.H., Mienert, J., Rumohr, J. \& Werner, F. 1998. The Norwegian-Greenland Sea continental margins: morphology and late Quaternary sedimentary processes and environment. Quaternary Science Reviews, 17, 273-302.

Wellner, J.S., Lowe, A.L., Shipp, S.S., Anderson, J.B., 2001. Distribution of glacial geomorphic features on the Antarctic continental shelf and correlation with substrate: implications for ice behaviour. Journal of Glaciology, 47, 397-411.

Wilken, M. and Mienert, J., 2006. Submarine glacigenic debris flows, deep-sea channels and past ice-stream behaviour of the East Greenland continental margin. Quaternary Science Reviews, 25, 784-810.

Woodworth-Lynas, C.M.T., Josenhans, H.W., Barrie, J.V., Lewis, C.F.M. and Parrott, D.R., 1991. The physical processes of seabed disturbance during iceberg grounding and scouring. Continental Shelf Research, 11, 939-951. 

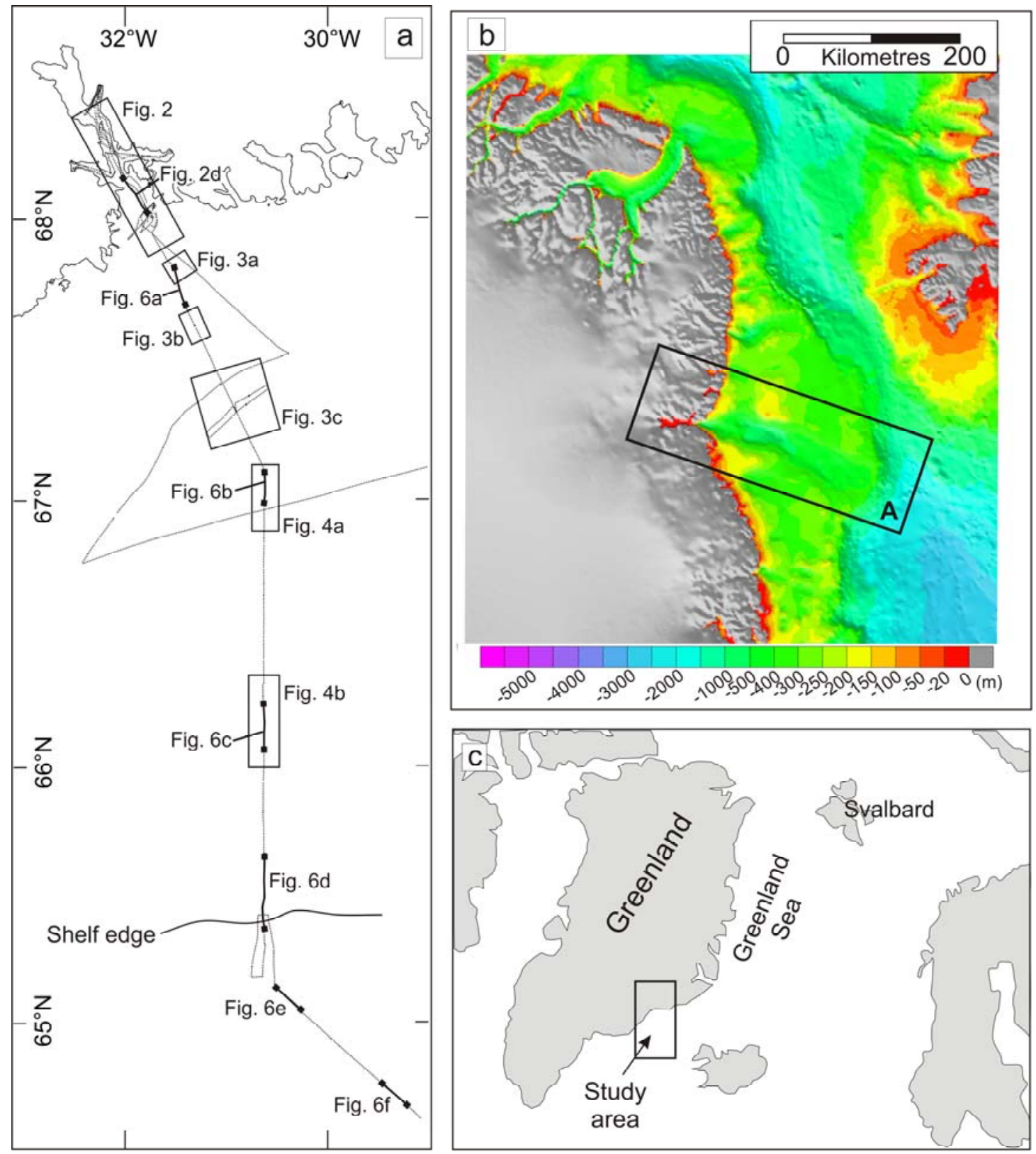

Figure 1. (A) Map of the Kangerlussuaq fjord-shelf slope system, East Greenland margin, showing track-lines of our geophysical data coverage. Subsequent swathbathymetric images and sub-bottom profiles are located. (B) Bathymetric map of the East Greenland shelf. (C) Location of study area on Greenland. 

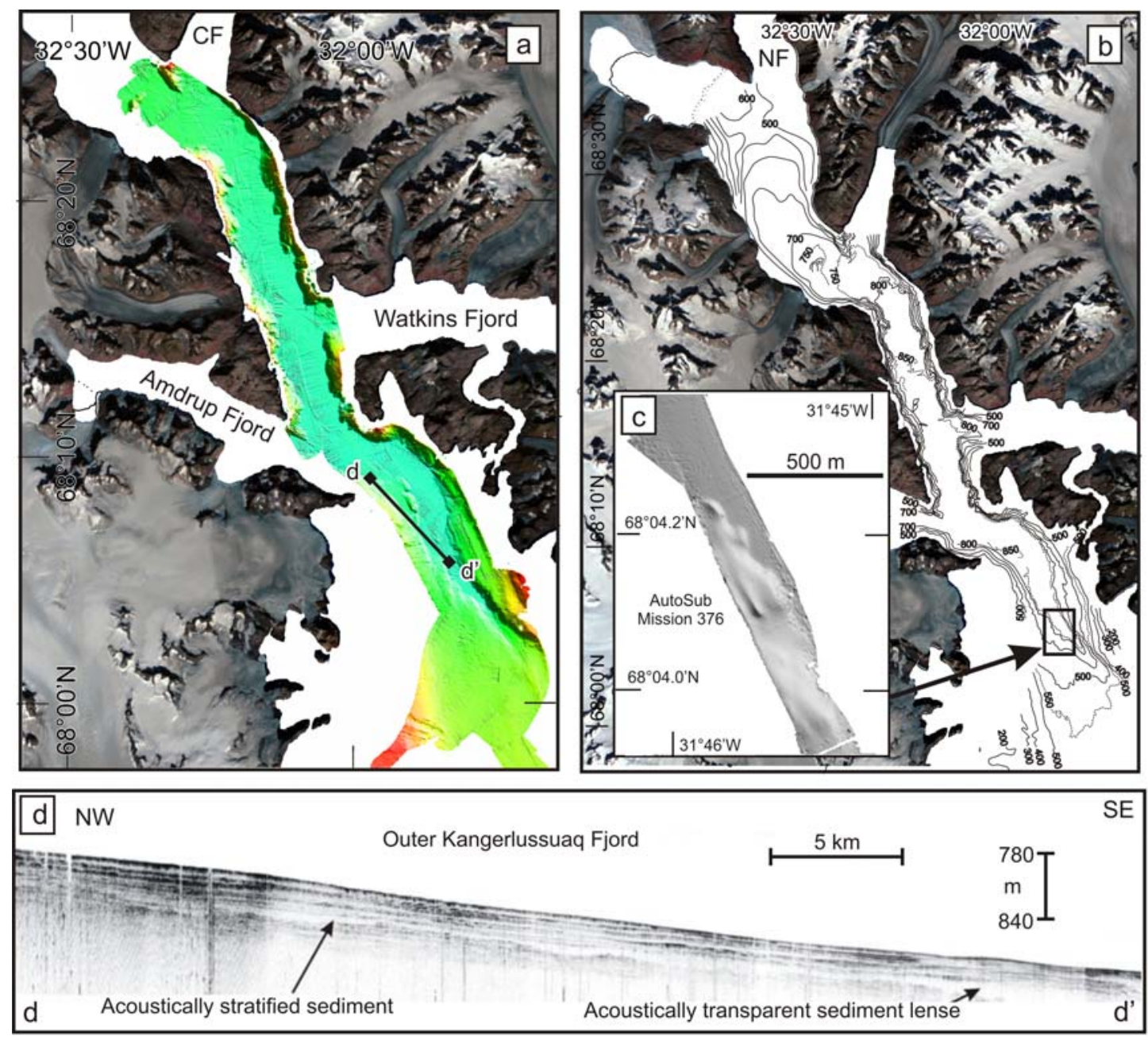

Figure 2. Swath bathymetrice imagery and TOPAS records from Kangerlussuaq Fjord. (A) Swath bathymetry from the EM-120 system on the RRS James Clark Ross superimposed on a Landsat satellite image of the surrounding glaciers and mountains. CF is Courtauld Fjord (B) Bathymetric contour map of Kangerlussuaq Fjord produced using data from part A and from Syvitski et al. (1996). The location of the sikusssak, or multi-year shorefast sea ice that broke up in August 2004 is to the left of the dotted line at the fjord head where bathymetric contours cease. (C) High-resolution EM-2000 data acquired from the Autosub autonomous underwater vehicle (located in part A). (D) TOPAS sub-bottom profile along the central axis of Kangerdlusssuaq Fjord. 

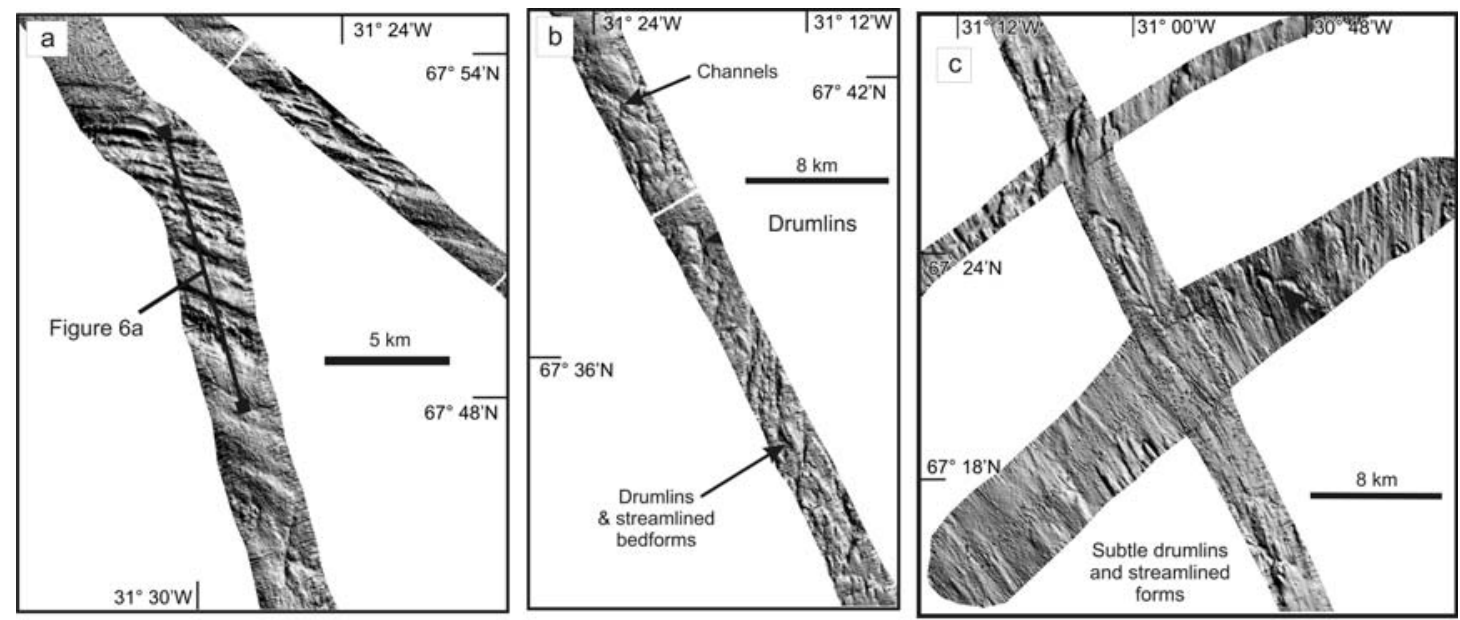

Figure 3. (A) Swath bathymetry of draped bedrock. Iceberg scours are also present at the top left of the image. (B) Swath bathymetry of channels and drumlins. (C) Swath bathymetry of drumlins, sedimentary lineations and crescentic features. The swath images are located in Figure 1A.
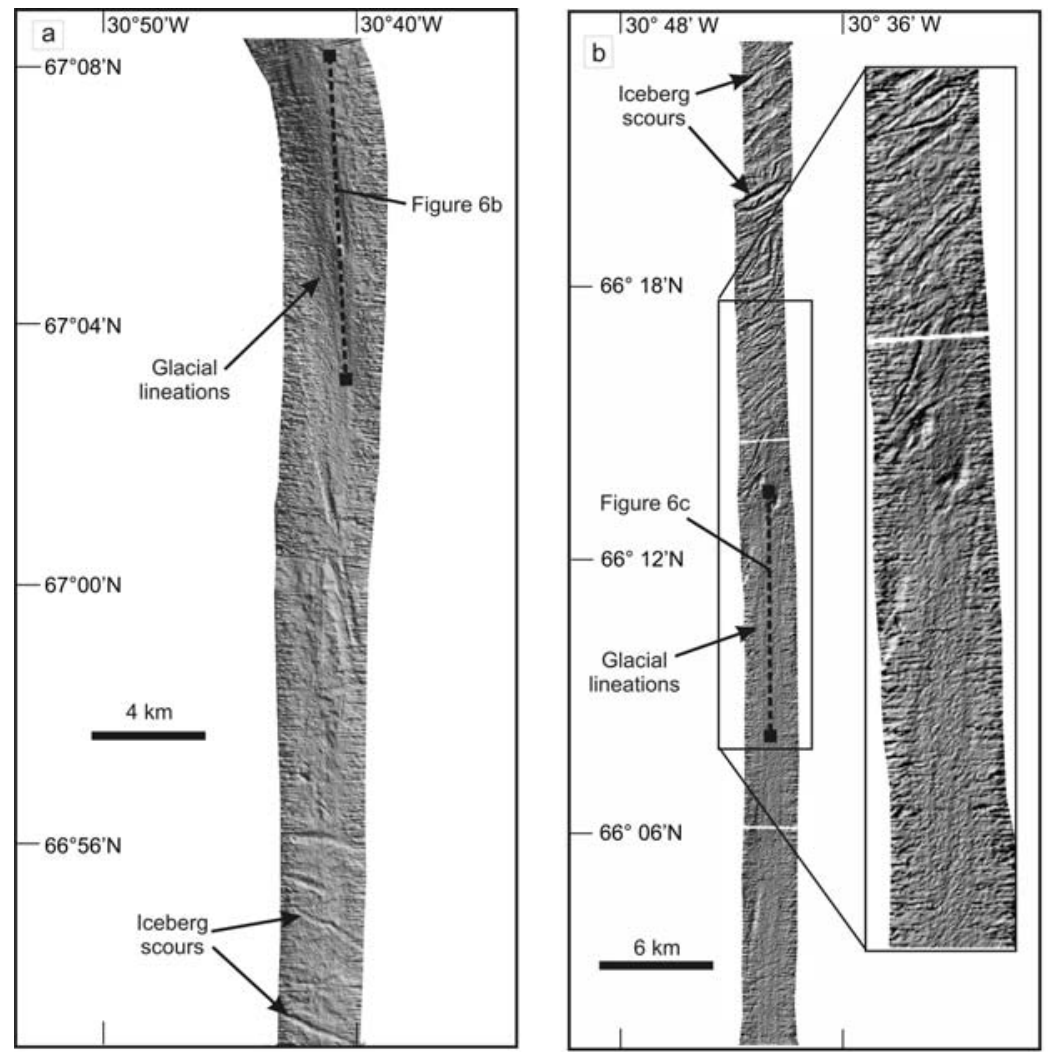

Figure 4. Swath bathymetry of two parts of the outer shelf showing subdued sedimentary lineations and occasional iceberg scours. The swath images are located in Figure 1A. 


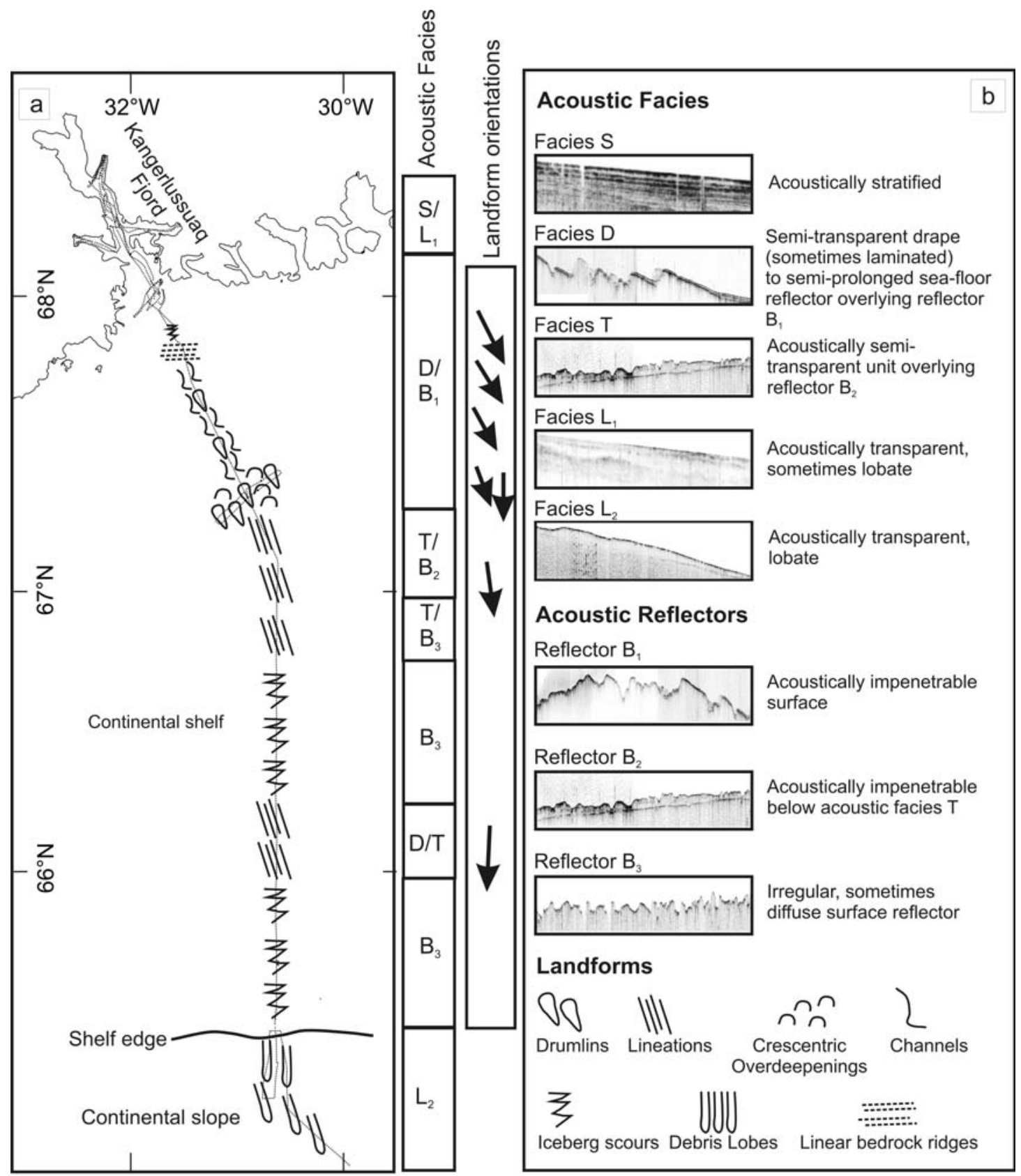

Figure 5. Character and distribution of shallow-acoustic units and submarine landforms in the Kangerlussuaq fjord-shelf-slope system. (A) Location map with the distribution of submarine landforms shown. The distribution of acoustic facies and landform orientations along the fjord-shelf-slope transect are also shown. (B) Examples, descriptions and interpretations of acoustic units and reflectors in the Kangerlussuaq system. 

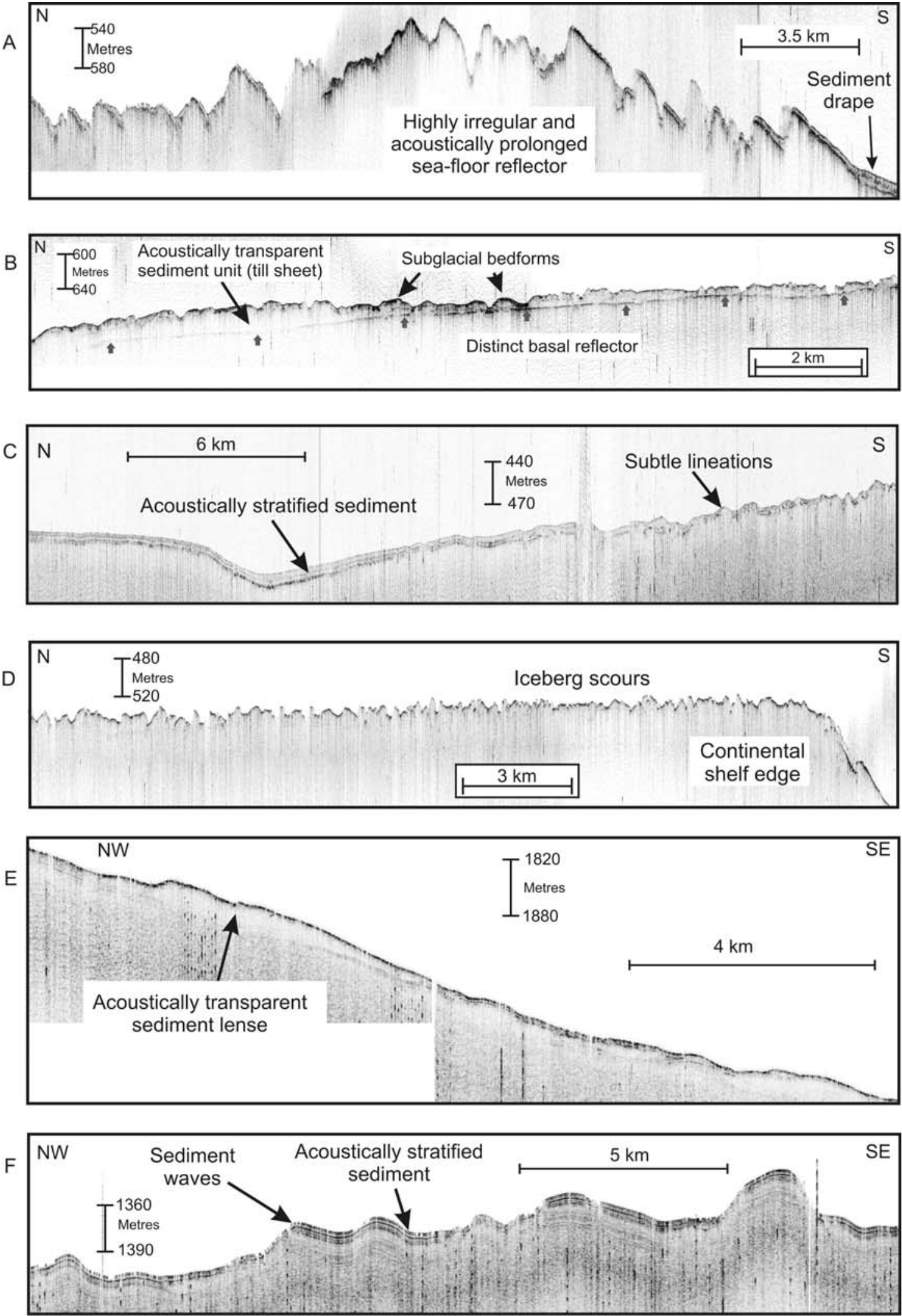

Figure 6. TOPAS sub-bottom profiler records from the Kangerlussuaq Trough and adjacent slope along a N-S transect from the fjord mouth across the shelf edge (located in Figure 1A). (A) Inner-mid shelf. (B) Mid shelf. (C) Outer shelf. (D) Shelf edge. (E) Base of the continental slope. (F) Upper slope. 